\title{
Water-Power Developments in the United States
}

\author{
By Dr. Brysson Cunningham
}

I $\prod_{\text {its other activities, renders an important }}^{\text {HE United States Geological Survey, among }}$ service to hydrological science by collecting and

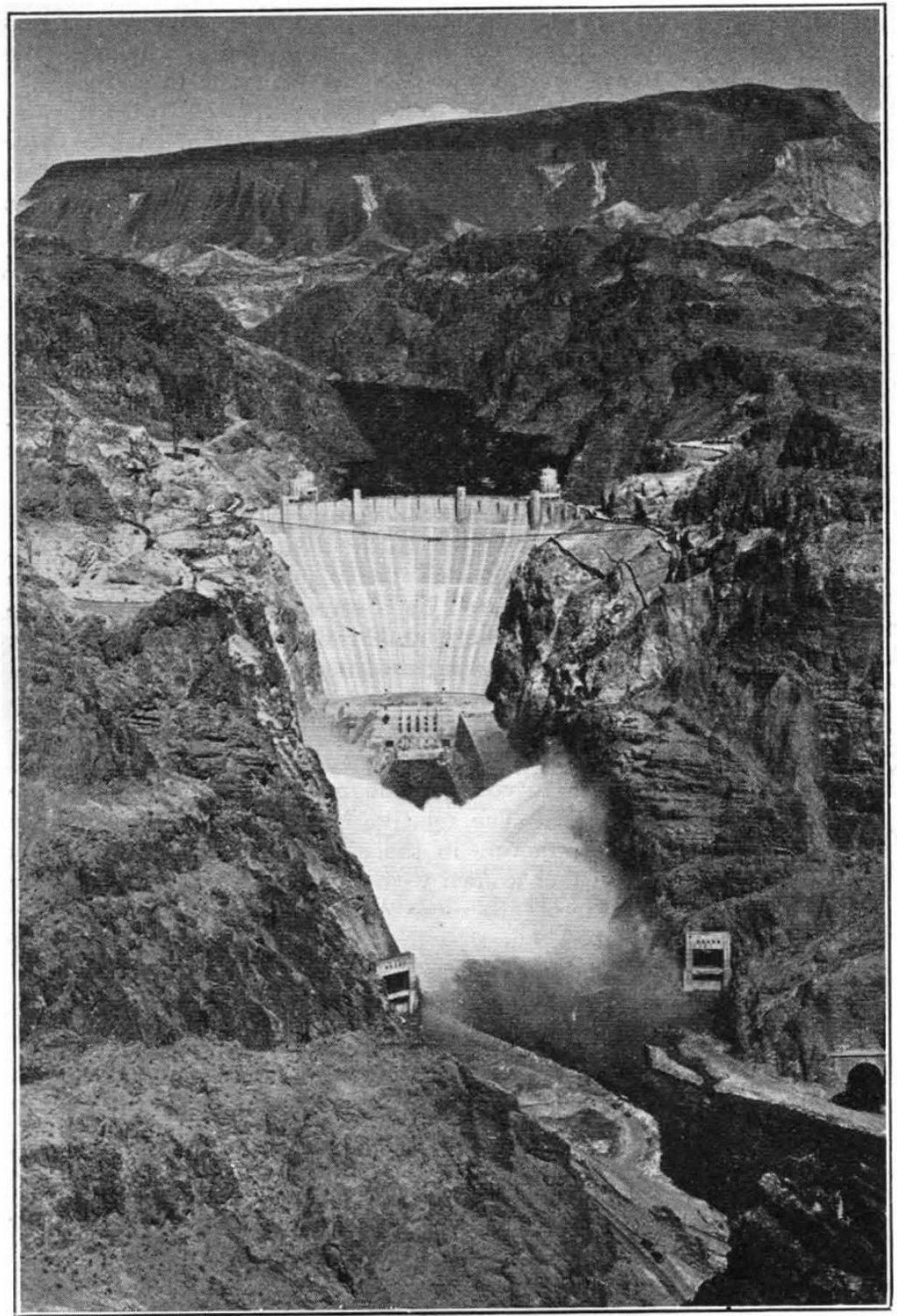

Fig. 1 .

View of Downstream face of Boulder Dam; in the distance is Fortification Modntarn.

publishing information on the amounts of developed and potential water-power throughout the world, the returns of the former and the estimates of the latter, of course, requiring periodical revision as the development of water-power proceeds. From the latest statement issued by the Survey, it is to be gathered that the total amount of horse-power actually harnessed at the end of 1934 was 55 millions, as com. pared with 46 millions in 1930, 33 millions in 1926, 29 millions in 1923 , and 23 millions in 1920 an increase of nearly 140 per cent in fourteen years.

As regards the potential developments, estimated on the basis of ordinary minimum flow and an efficiency of 70 per cent in installation, the following brief summary of continental aggregates is of interest: Europe, 58 million horse-power; Asia, 80 millions ; Africa, 190 millions, of which no less than 125 millions is located in the basin of the Congo and adjacent territory ; Oceanica, 17 millions; and America, 127 millions, of which 73 millions is in the northern hemisphere, and 54 millions in the southern.

Developed horse-power at the present time is spread over the world in the following approximate amounts: Europe, 24,300,000 ; Asia, 4,900,000 ; Africa, 115,000 ; Oceanica, 550,000 ; North America, 24,400,000, and South America, 1,000,000. In comparing these figures with those for potential exploitation, allowance must be made for the fact that the former are based on the actual capacity of the machinery installed, which averages from two to three times the potential power at low flow at the same sites.

A notable fact from the statistics is that Europe has practically caught up with North America in the capacity of actual installations. As against this must be set the fact that the unit magnitudes of certain installations in hand in the United States far exceed those of any other installation under construction in the world. Four outstanding 
examples may be mentioned: the Boulder Dam, on the Colorado River on the joint boundary of the States of Nevada and Arizona; the Norris Dam, on the Clinch River in North-Eastern Tennessee ; the Bonneville Dam, on the Columbia River, at Bonneville, Oregon, and the Grand Coulee Dam, also in the Columbia Basin, but in the State of Washington. These undertakings are of such striking magnitude as to claim some detailed notice. The following descriptions are compiled structure enables the water surface of the Colorado River to be raised $584 \mathrm{ft}$. It is located on the Arizona-Nevada State boundary line, in upper Black Canyon on the Colorado River, about 30 miles south-east of Las Vegas, Nev., and 80 miles north of Needles, Calif. The natural geological formation of the site is andesite breccia, hard and very durable.

The dam, the downstream face of which, as it appears from a mountain top on the Nevada side

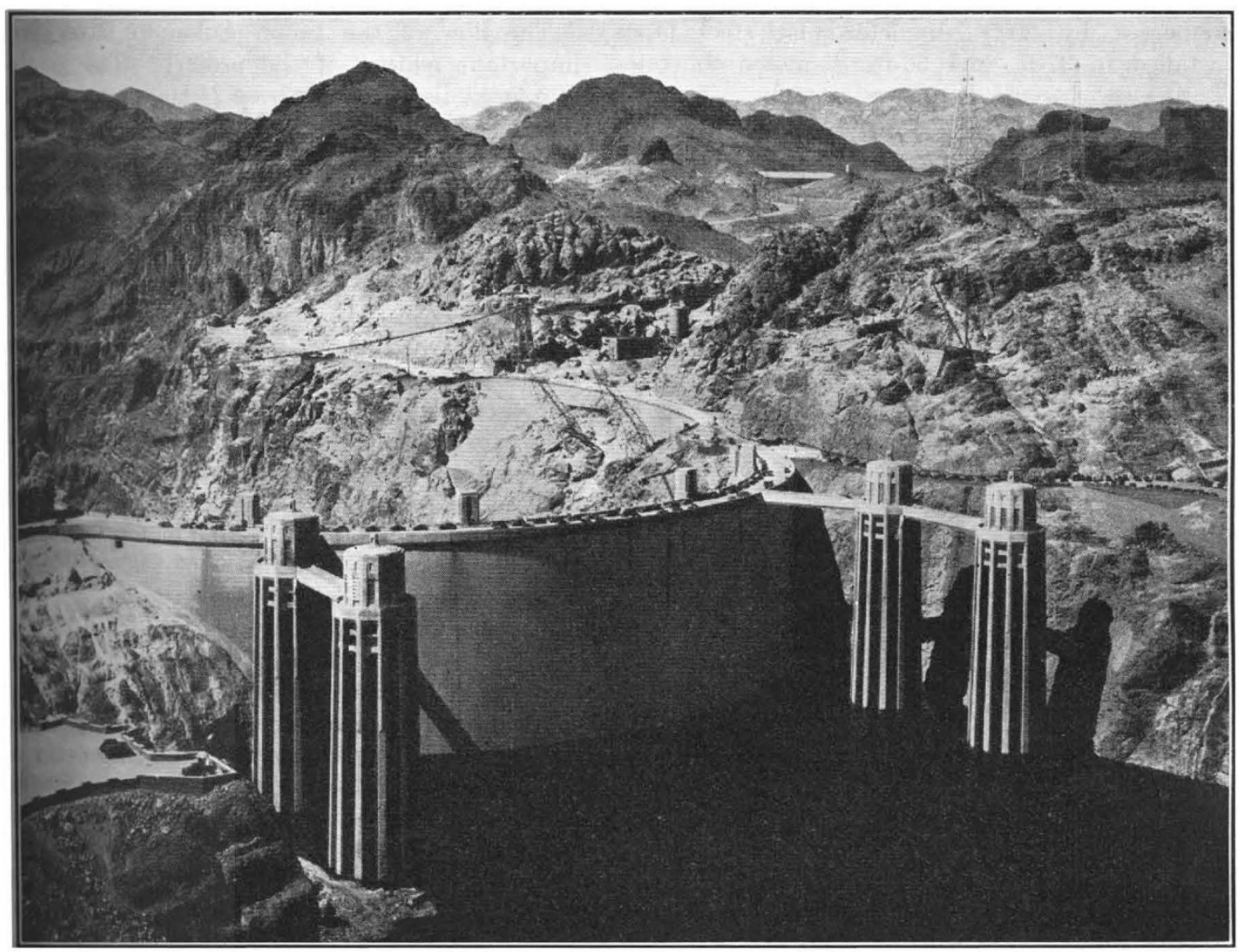

Fig. 2 .

View of upstream face of Boulder Dam, showing impounded Lake Mead.

from information kindly supplied by the authorities concerned.

\section{The BOULDER DAM}

The Boulder Dam, perhaps the most notable of the four, has already received a brief preliminary notice in this journal (Nature, Feb. 9, 1935) just before its completion in May 1935*. It is by far the highest dam in the world, with a height of $726 \mathrm{ft}$. above bedrock foundation, as compared with $450 \mathrm{ft}$., the height of the Chambon Dam in France, which at present ranks second in altitude. The crest length is 1,282 ft., and the

* It also formed the subject of a lecture delivered to the Institution of Civil Engineers on April 15 (vide NATERE, April 24, p. 706). of the Black Canyon, is shown in full extent in Fig. 1, is of the arch-gravity type, and contains $3,255,000$ cubic yards of concrete, weighing somewhat less than seven million tons. The artificial reservoir formed by the dam has a capacity of $30 \frac{1}{2}$ million acre feet : it is 115 miles long, with a superficial area of 146,500 acres, or 229 square miles, and the filling with water is taking a period of about three years to complete. The view (Fig. 1) shows twelve discharge outlets fully open, resulting in two great cascades with a fall $13 \mathrm{ft}$. more than the Niagara Falls.

The upstream face elevation above the level of an intermediate impounding stage in Lake Mead 
with a depth of more than $330 \mathrm{ft}$., is shown in Fig. 2. Motor-cars can be seen parked in the four-lane roadway across the dam. As will be seen, there are four reinforced-concrete towers located adjacent to the dam, two on each side of the river, and about $165 \mathrm{ft}$. apart in a direction parallel to the stream. The towers are $375 \mathrm{ft}$. in height, and average $75 \mathrm{ft}$. in diameter, decreasing from $82 \mathrm{ft}$. at the base to $63 \mathrm{ft}$. at the summit. Each tower controls a quarter of the water supply to the power plant turbines, to which they are connected by $30-\mathrm{ft}$. diameter plate-steel pipes installed in $37 \mathrm{ft}$. and $50 \mathrm{ft}$. diameter concrete-

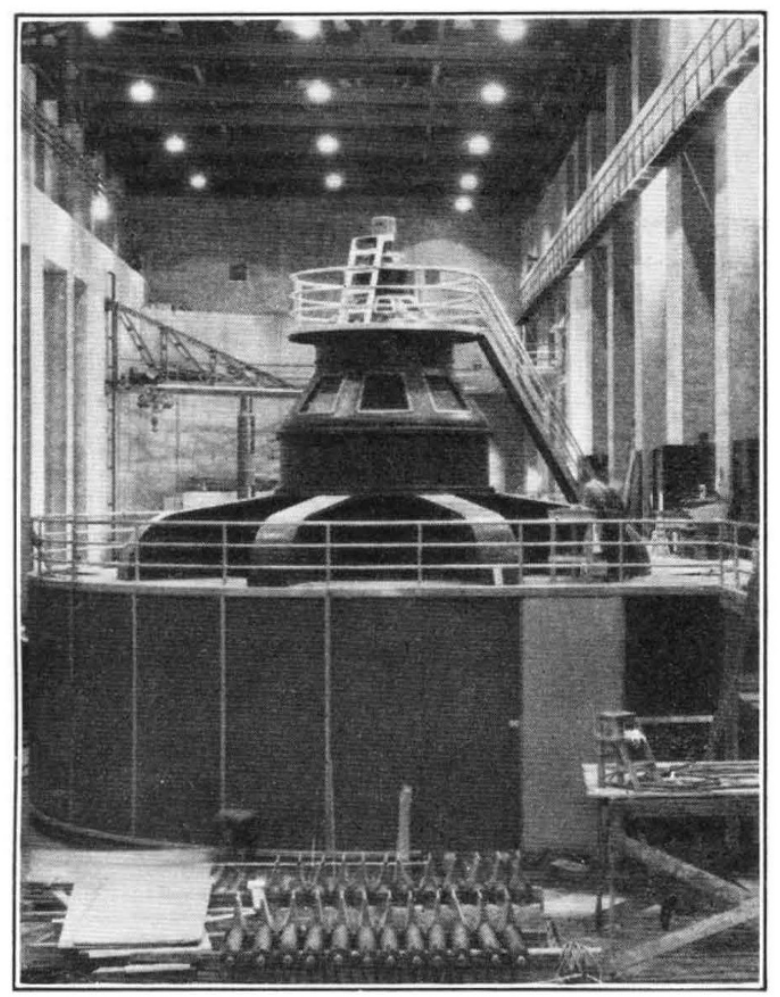

Fig. 3.

82,500 KILOVOLT-AMPERE GENERATOR IN BOULDER DAM Power House.

lined tunnels. Each tower has two cylindrical gate valves, $32 \mathrm{ft}$. in diameter and $10 \mathrm{ft}$. high, one near the bottom, and the other about mid-height.

Power development is contemplated to the extent of 1,835,000 rated horse-power. For comparison, it may be mentioned that the total horsepower at Niagara (United States) is 452,500 , and at Dnieprostroy (U.S.S.R.) 750,000. A view of the power house is given in Fig. 1 above, and a view of the interior, showing one of the gigantic generators (capacity 82,500 kilovolt amperes) in operation since October 1936, is given in Fig. 3. Four 115,000 horse-power turbines are being installed at the outset, together with a fifth of
55,000 horse-power. The main plant units are unexcelled in magnitude in the world: they have a capacity nearly twice as great as any previously constructed - -the nearest approaching them being the 83,000 h.p. turbines and the 76,500 kilovolt ampere generators at Dnieprostroy. The Boulder installation will be complete with fifteen large, and two smaller units about 1940, when about 663,000 horse-power will be continuously available, based on 83 per cent plant efficiency and 10 per cent maximum shortage.

The flow of the Lower Colorado River is an important feature of the project. The greatest measured discharge has been 240,000 cusecs (cubic feet per second) at Yuma, Arizona, but an abnormal flood is believed to have reached 300,000 cusecs for a short period in 1884. At the other end of the scale, the discharge has fallen to 66 cusecs, also measured at Yuma. At the site of the dam, the average discharge is 21,000 cusecs with an average annual run-off of $15,069,000$ acre feet.

In addition to power generation, the water from the impounded area is to be used for irrigation purposes. Below the Boulder Canyon reservoir there are some $1,900,000$ acres of irrigable land in the States of Arizona, California and Nevada, of which hitherto only 660,000 acres have been under irrigation. There is, therefore, abundant scope for further extensions of supplies of water for irrigation purposes.

Another feature of the project which should not be overlooked is the "All American" Canal, so called because it lies entirely in the United States, while the present Imperial Main Canal is largely in Mexico. The new canal will lead from the Colorado River to the Imperial and Coachella Valleys. The intake is at the Imperial diversion dam, at a site about 15 miles north-east of Yuma, Arizona. The length will be 80 miles to the Imperial Valley, and that of the main canal to the Coachella Valley, 130 miles. A maximum diversion of 15,000 cusecs of water is planned. The canal widths are $232 \mathrm{ft}$. at the surface and $160 \mathrm{ft}$. at the bottom, with $20.6 \mathrm{ft}$. depth. There are only two larger canals in the United States, both ship canals.

The Boulder Canyon Act authorized expenditure up to 165 million dollars (33 million pounds) on the project, of which 70 million dollars is the estimated cost of the dam and reservoir, 38 millions the cost of power development, and a similar sum the cost of the "All American" canal. Up to 1936 about 110 million dollars had been expended.

The photographs illustrating this article have been courteously supplied by the Bureau of Reclamation, Department of the Interior, Washington, D.C., U.S.A., as also, in conjunction with the U.S. Geological Survey, the information on which the article is based. 